\title{
5. Engendering Violence in the Papua New Guinea Courts: Sentencing in Rape Trials ${ }^{1}$
}

\author{
Jean G. Zorn
}

\section{Abstract}

Rape is endemic in Papua New Guinea, and the courts in Papua New Guinea have not been effective at decreasing its incidence. This may be in part because the very courts that are supposed to be a bulwark against the culture of engendered violence are themselves part of it. Some judges today are beginning to adopt a more empathetic view towards the women who are victims of sexual attacks, but most judges in Papua New Guinea, both expatriate and indigenous, from the colonial period onward, have found it impossible to take women's pain (especially emotional pain) seriously, and therefore have not taken rape seriously. Many judges view it as prurient, but not violent. Many of them continue to believe, despite evidence to the contrary, that most women who are raped probably 'asked for it'. As a result, although new sentencing guidelines introduced by Parliament allow for much longer gaol sentences for rape than were possible in the past too many judges find ways to give shorter sentences than the guidelines would permit.

\section{Introduction}

Crimes of sexual violence such as rapes and sexual assaults of women and children, are disturbingly prevalent in Papua New Guinea (PNG), and are all too often carried out in a particularly sadistic and gruesome fashion. Parliament and the Papua New Guinean courts all recognise the gravity of the problem and have attempted to use the law to decrease the incidence of these crimes. Over the last thirty years, the courts have gradually increased the length of prison sentences for persons convicted of rape. Prior to the amendment of the PNG Criminal Code by the Criminal Code (Sexual Offences and Crimes Against Children) Act

\footnotetext{
1 I wish to thank all of the members of the ASAO panel on 'Engendering Violence' for their suggestions and support, especially Christine Stewart, Dorothy Counts and Margaret Jolly. My special thanks to Stephen Zorn and Carolyn Brewer without whose excellent editing this piece would have been neither as concise nor as cogent.
} 
2002 (Sexual Offences Act), the applicable provision of the Code, then Section 347, gave the courts broad latitude in determining sentences for rape. Among other changes to the Code, the Sexual Offences Act divided the crime of rape into two categories: ordinary and aggravated. The Act set the penalty for ordinary rape at fifteen years and made offenders convicted of aggravated rape liable for penalties up to life imprisonment. I am not in a position to assess the extent, if any, to which passage of the Sexual Offences Act has contributed to a decrease in crimes of sexual violence. What I do in this chapter is to analyse the ways in which the courts have responded-first to crimes of gender violence (the chapter focuses on rape of women) and then to the new Act. The PNG courts are very ambivalent about rape. On one hand, the judges say, over and over, that rape is widespread, that the 'community' is deeply upset by it, and that something needs to be done to decrease the incidence of rape. At the same time, however, the courts initially set prison terms for rape at very low levels and have increased them only very gradually.

The source for this ambivalence on the part of the judges can be traced to women's subordinated status in PNG. Most of the judges are men and they have been since colonial times. To the end of the colonial era, almost all the judges came from Australia, a very few from other Commonwealth countries. None were Papua New Guinean or even from other Pacific nations until after Independence. The judges, therefore, are most accurately reflecting the beliefs and values of PNG's male-dominated communities (both indigenous and expatriate) when they say that, in and of itself, rape is neither violent nor even particularly painful, either physically or emotionally. This stems from their ingrained notion that women act more emotionally than men so that, somehow, women's emotions are not as strong or real as men's, and psychological trauma is not as real as a wound from a bush knife or gun. It is an interesting albeit distressing paradox that many judges perceive women to be stereotypically more emotional than men, whilst at the same time, or perhaps as a result of this, they fail to register either the physical or the emotional pain that rape inflicts on women.

The judges in PNG operate in a society that has inherited its views of women from three sources. First, sexual distance and - in some areas of the countrysexual aggression were (and still are) integral parts of many pre-colonial cultures. Second, sexism was also characteristic of PNG's German and British colonisers. ${ }^{2}$ And third, sexism is a by-product of the rapid and uneven development, or lack of development, that has characterised PNG's post-colonial history. So it is no surprise that sexism is prevalent, though not universal, amongst the members of

2 For lack of a more precise term, I am using the word 'sexism' to describe the approach that too many PNG judges take to the crime of rape. Sexism is a term frequently heard, but seldom defined. While the term is too broad to capture the complex and often contradictory emotions, values and beliefs of Papua New Guinea's lawyers and judges, sometimes a mutually understood shorthand is needed. By 'sexism', I mean simply a mode of thought that positions women as subordinate to men. 
PNG's legal profession, including its judges. Systemic sexism is a cause both of the pervasiveness of rape in PNG and of the courts' tepid response to it. In her chapter in this volume, Laura Zimmer-Tamakoshi explains some of the reasons for the relationship between sexism and rape:

In many PNG societies, the basis for the subordination of women and the exploitation and manipulation of their sexuality was older men's control of most economic resources and male ideologies which portrayed women as dangerous, inferior, and untrustworthy creatures who were to be feared, kept under control, and avoided whenever possible. Such ideologies were directed primarily at young men as a means of keeping them away from women until the young men's elders felt it was time for them to marry. At the same time, the use of rape and physical violence to control 'unruly' women was commonplace and young men were sometimes encouraged to participate in the rapes and sexual abuse of women.... For young men who opt (or are forced) to stay in town, unmarried and unrespectable by their parents' standards, joining gangs of other young men who make their own rules and standards is an attractive, albeit ultimately dead-end, proposition (Ch. 2).

Not all judges are equally impervious to the pain caused to women by rape. As early as the mid-1980s, a few judges were urging their colleagues to adopt the more victim-centred policies that have long since been adopted by Australian, British and American courts (Zorn 2010: 14). And, more recently, whilst Australian male judges on the Papua New Guinean bench have continued to insist that, in and of itself, unaccompanied by a knifing, beating or other physical injury, rape does not involve much pain or violence, some indigenous judges appear more empathetic, although this appears to be primarily where village women (rather than urbanised women) are the victims.

Still, almost every case in PNG determining the fate of a man who has raped or otherwise sexually abused a woman is decided by a man; the length and nature of the sentence is determined by a man; and it is a man who writes up the case, in a document called a 'judicial decision', in which he lays out his reasons for the sentence. Today, it is impossible to read these decisions without reference to feminist legal scholarship, which first posited the notion that the law itself is inherently male, not only in its overt attitudes towards women and women's bodies, but also in its glorifying of masculine values, such as reason and autonomy (Thornton 1998; Grbich 1991: 75). An analysis of the decisions would suggest that Marilyn Strathern (1988) is incorrect in her insistence that Papua New Guinean cultures do not hold to the same gender bifurcations that dominate the perceptions of women by men in other (primarily western) cultures. But, given the heavy influence of western legal categories on PNG's legal system and on its judges, one would hesitate to draw that conclusion. 


\section{Limits on the sanctions available to the courts}

It must be said that the continuing epidemic of gender violence in PNG, including the high incidence of rape, cannot be laid entirely at the judges' door. Even the most sexist of PNG judges have responded to the high incidence of rape by gradually increasing prison sentences so that, overall, sentences for rape have increased, from an average of nine to twelve years in the mid-1980s to an average of fourteen to nineteen years today. The primary reason for the increase, ironically enough, is that the ever-more-severe sentences are not succeeding in decreasing the number of rapes. Quite the contrary, the number and gruesomeness of rapes have increased markedly in PNG, particularly in urban areas, in the last twenty-five years. Rapes are increasingly a side-effect of robbery involving gangs of men or youths repeatedly raping a victim over a period of several hours or days. But, despite the trend toward longer sentences, the effects of the inherent sexism of Papua New Guinean cultures and of its legal system are still evident.

If longer sentences have little effect on rape, then we must look to other remedies, but the courts are unable to come up with any means, other than making sentences longer and longer, to deter future rapists. There are at least three reasons for this. First, the narrow Anglo-Australian judicial tradition limits the kinds of sanctions that a judge may employ. Second, there are forces beyond the control of judges, principally the unwillingness or inability of other governmental and non-governmental agencies to do what the courts themselves are neither funded nor authorised to do. Finally, the various male sub-cultures within PNG, sub-cultures of which its male judges are a part, seem unanimous in their dislike or fear of, or distance from, women.

There are only a few tools that legal traditions (and statutes) authorise judges to employ: sentencing defendants to a term in prison, with or without the possibility of an early release on parole; ordering a defendant to pay a fine; or sentencing the defendant to a suspended sentence for a term, which means the defendant will be free unless the terms of the suspension are violated. ${ }^{3}$ In tandem with any of these sentencing options, judges can order the defendant to do community service. In PNG, there is an additional sanction available: judges can order defendants to pay compensation.

Judges are supposed to utilise these sanctions, singly or in combination, to attain the four goals that are constantly cited as the main aims of the criminal law: (1) rehabilitating the defendant; (2) deterring the defendant from committing further crimes; (3) protecting the community against further bad acts by this defendant; and (4) deterring others from committing similar crimes. The

3 PNG Criminal Code, Section 19. 
limited range of sanctions available to the courts is not always best suited to the attainment of these goals. Prison, for example, is more likely to teach young offenders how to commit more serious crimes than it is to rehabilitate them, and much research has proven that the spectacle of offenders going to prison does not necessarily deter others from committing the same crimes.

Moreover, judges are dependent on other governmental and non-governmental agencies for assistance. For example, a judge can sentence a defendant to a prison where, the judge hopes, rehabilitative services such as educational facilities and counselling will be available, but if the state has not seen fit to provide such services there is little the judge can do. PNG prisons offer little in the way of education, counselling or any other kinds of assistance that might improve prisoners' lives and deter them from committing more crimes. Moreover, judges may presume that there is community oversight of defendants who are on probation or serving a suspended sentence. In PNG, that is almost never the case.

Different goals have assumed precedence in different cultural milieux and at different moments in history. The eighteenth-century emphasis in England and the European continent on protecting the community from the criminal had led to the creation of fortress-like prisons, many of which were located on islands far from European settlement, as well as to the use of Australia and parts of the United States as penal colonies. This was followed in the nineteenth century by an emphasis on rehabilitation, exemplified by the adoption of new names for prisons, like penitentiary and correctional institution (Foucault 1975). In PNG today, at least where rape is concerned, deterrence-both the specific deterrence of the defendant from committing further crimes and the more general deterrence involved in persuading others to abstain from committing similar acts - has become the primary goal of the judiciary.

There are at least two ways in which the courts could play a more effective role in reducing the incidence of rape in PNG. One way would be to take rape more seriously, consciously recognising the pain it inflicts, and to impose sentences that reflect such pain. A second would be to persuade other governmental and non-governmental agencies to devote more resources to solving the problem. Neither is likely, in large part because of the bias against women. This bias is characteristic both of Papua New Guinean culture generally and of the specific sub-culture in which the judges have been educated and in which they lead their professional lives. Despite the judges' sincere hatred for the crime of rape, they too are prisoners of the sexism of their society and of their own sub-culture.

The judges' own written decisions demonstrate the insidious impact that the combined sexism of PNG generally and of legal institutions in particular has had on the courts' ability to devise sentences that contribute in any meaningful 
way to decreasing the incidence of rape in PNG. In two landmark cases, both decided in 1987, State $v$ Kaudik and Aubuku $v$ State, ${ }^{4}$ the courts adopted 'starting points' (ranging from five to eight years) for determining how long a convicted rapist should be incarcerated. These 'starting points' were to be added to, or occasionally subtracted from, depending upon the existence, in the rape itself and in the defendant's background, of aggravating factors or mitigating circumstances. Aggravating factors might include the degree of violence associated with the crime, or the relationship between the rapist and his victim: was he, for example, abusing a relationship of trust? Mitigating factors include the age of the defendant (ordinarily, youthful offenders receive lighter sentences) or his criminal record (the lighter the record, the lighter the sentence). The judges adopted these guidelines intending to create a set of rules that would be fair and neutral in application. As I will demonstrate, however, the guidelines are infused with sexism, both in substance and in application.

\section{Deconstructing sentencing decisions}

There are multiple ambiguities at the centre of the judges' masculinist views of rape. Feminist theorists have long posited that rape is, primarily, an act not of sexual longing, but of violence which the rapist perpetrates on a woman primarily in order to cause her pain and suffering (Brownmiller 1975; Bourke 2007). But feminist scholarship also confronts the conundrum that in cultures like most of those in PNG, including those of the urban centres, men's views of women's ability to feel pain and suffering are paradoxical and contradictory. Men believe that women feel too much, that they follow their emotions when they ought to be guided by reason. At the same time, men believe that women are not fully human, that although women are over-emotional creatures, they do not have feelings in the same deep way that men do. So rape is also an exercise in frustration for the rapist, who is trying to cause pain and fear in a person who, he believes, is not capable of experiencing true pain or fear. Thus, women are, at the same time, too human and not human enough, too emotional and not emotional enough (Lloyd 1984; Lutz 1998).

Judges are products of their gender, class and conditioning. Neither Papua New Guinean nor expatriate judges can escape the cultures in which their ideas were formed. The legal profession, which was for a long time a male-only bastion, still has a culture of masculinity. There are, as R.W. Connell $(1987,2005)$ has made us realise, many masculinities. That of the courtroom is a masculinity derived not

4 Only the names and dates of the cases are given in the text. Generally, the full decisions can be found by searching, under the appropriate name and year, either in the printed Papua New Guinea Law Reports, published annually, or at Papua New Guinea Laws, PacLII database, online: http://www.paclii.org/databases. html\#PG, accessed 5 November 2011. 
from violence and physical strength, but from privilege, reason and logic (Collier 2010, 431; Dowd 2010). It is, therefore, an axiom of the (western, including colonial) legal system that judges decide cases and hand down sentences based upon law and logic. Everyone connected with the legal system-including the judges themselves - believes this to be true. Emotions are supposed to play no part in judicial decision making; instead, reason and logic are supposed to be transcendent. So, to the members of the legal profession, it is a display not of feeling for the victim, nor even of anger at the accused, but of logical, rulebased argument that gives judicial decisions their legitimacy. It is presumed that judges decide fairly and honestly, by a logical application of the law to the facts of the case, and not by the subjectivity or bias of feeling, culture or kin. This same conceit is also another aspect of the sexism of the western legal system: reason and logic are associated with maleness; emotions like envy, bias or greed that would colour decision-making are associated with femaleness - a dichotomy in masculinist thinking that has been central to feminist analysis at least since Sherry Ortner and Harriet Whitehead (1981). To the extent that the law is praised (by judges and lawyers) for eschewing emotion in favour of reason, it is being praised for being male (Thornton 1998; Dowd 2010).

However, a close reading of judges' decisions - not only in PNG, but in any common law jurisdiction - uncovers depths of emotion, and the clear suggestion that the judges' choices are as impelled by these emotions as they are by reason. Although it is true that the vast majority of articles in law reviews treat legal argument and judicial decision making as if they were based solely on reason, there is also a significant body of work pointing out that legal decisions are equally influenced by emotions, values, biases and experience. Scholars writing from this perspective include critical legal scholars, feminists, critical race theorists and others, loosely grouped under the rubric 'Outsider Scholarship', a term which in itself suggests how far from the mainstream this view continues to be (Coombs 1992; Valdes 1999; Foley 2010: 26). This approach to the texts reveals that judges share the same ambiguous and mutually contradictory views of women held by other men (and, because they too were raised in that society, by most women). That is, the male judges are excited (and repelled) by the facts of rape, by the terror and pain of it, at the same time that, different and distanced from women, they cannot believe in the reality of women's feelings. Many of the decisions dwell, with what almost amounts to salacious interest, on the clinical and lurid specifics of the rape, featuring detailed descriptions of the degrading sexual acts that the rapists forced upon their victims At the same time, in the same decisions, judges write that the rape they have just described is not particularly painful, thus making a longer sentence for the crime unnecessary. And, though the judges write stock paragraphs about the psychological wounds caused to women by rape, they do so in such a rote fashion as to suggest they truly do not feel what they are saying. 
Unfortunately for the women, who feel pain, anguish, defilement and depression, the men who hear about their ordeal (including, I believe, judges) feel none of those. Although rape itself is not sex but violence, hearing about rape is all about the ways in which gender violence breeds sexual excitement.

\section{'Moira's' story}

We'll call her Moira. ${ }^{5}$ The written decision does not tell us her name, though it tells us a little about her. Moira and her family were expatriates. In 1986, when she was just seventeen and still in high school, her father took a position with a Papua New Guinean university. The University provided on-campus housing, and that is where Moira and her parents were living when she was the victim of a particularly brutal pack rape. She had spent the evening babysitting for the children of another couple who also lived on campus, and was about to get into her employer's car to go home, when a gang of eight men approached the vehicle, shotguns drawn, surrounding her employer and dragging her into the garden where her ordeal began. It would last for the entire night, and involve multiple rapes and other forms of sexual abuse by a number of gang members.

Like Moira's, many rapes in PNG are particularly violent, because, like this one, a very high number of rapes in PNG are pack rapes. Pack rapes have developed their own norms: they all seem to begin with a house or vehicle robbery and to include the subjugation of the victim's male companion, the abduction of the victim, hours of repeated sexual attack and what seem to be contests amongst the participants as to which of them can subject the victim to the most indignity. Of the cases that I randomly sampled (a substantial but still incomplete sampling of all those that have been preserved, either in PNG Law Reports or in PacLII), a very high number involved pack rapes - groups of men (usually young from their teens to twenties) abduct women (usually teenage girls or young women), typically as a sequel to a brutal armed robbery or house invasion. The victim is subjected to the horror of repeated group rapes, often throughout the night, sometimes for several days, with multiple defendants serially forcing sex upon the victim, often several times each.

\section{The facts of the case: the law as pornography}

It is possible to write a judicial decision in a fashion that omits the pornographic details, that does not strive for novelistic specificity, that does not dabble in graphic excess and that, nonetheless, conveys enough of the particulars to show that the elements of the crime were indeed proven. Yes, it is necessary to a rape

5 State $v$ Kaudik (1986). 
conviction to prove that sexual penetration occurred. ${ }^{6}$ But a judge does not have to describe it over and over - as happened in this case. Certainly, if a sentence longer than one of those at the 'starting points' is to be imposed, it is necessary to show aggravating factors, but, again, a judge can do this without dwelling on each and every penis being forced into the girl's mouth — as the judge did in this case.

Feminist legal theorists were among the first to note that unnecessarily detailed and repetitious descriptions, like those in the decision in Moira's case, are examples of legal description becoming pornography (see MacKinnon 1985: 1). There are many key resemblances between the decision and the kinds of writing found in pornographic magazines. For example, the decision never gives a name to the victim. We are told the name of the defendant (the rapist), we are even told the (completely irrelevant) name of the family for whom the victim was babysitting when she was abducted, but we are not told her name. The law's reason for refusing to name the victim is to protect her and perhaps, while it succeeds in protecting one young woman, it does so at the expense of women generally. Because namelessness reduces women to objects, and objectification and anonymity allow readers to revel in the arousal that the sexually explicit descriptions elicit, without having to feel the guilt or shame that would occur if the victim were somebody real, somebody with a name. At the same time as the decision permits distance, by depriving the victim of the personhood that comes with having a name, it also invites a certain voyeuristic intimacy, by obliging the victim to recapitulate every horrifying and sordid moment in the first-person narrative of her affidavit. She is violated twice, first by the rape itself, and then by this legal process.

First-person narratives invite the reader into the sensual experience, give it texture and immediacy; the first-person narrative allows, even invites, the reader to join in the sexual acts, which may be why most best-selling pornography is written in the first person, often in the person of the woman/victim (e.g. Réage 1954). The first-person narrative has another purpose as well: it allows the judge to avoid responsibility for its pornographic aspects. By ostensibly quoting from the victim's affidavit rather than recasting it in his own words, the judge can pose as uninvolved in the sexual details; even though he is the one behind the scenes, orchestrating the words and choosing what will go into the decision and what will not.

6 At the time this case was decided, the Code did not refer to 'sexual penetration' but to 'carnal knowledge'. This Victorian attempt to avoid saying what was meant caused difficulties for the courts when sexual assault consisted of anything other than the straightforward penetration; in those cases, under that prudish statute, was it or was it not rape? The more explicit and therefore much more helpful term 'sexual penetration' has now been substituted. 
When a decision dwells on the specifics of the rape, it could be to demonstrate the judge's own horror at those details, to make sure he has shown that the prosecution has proven every element of the crime, or to convince readers of the pressing need for a longer sentence. However, the evidence is against any of these being the major reason. In general, and barring a few exceptions, the longer the sentence, the less the picturesque detail. Catharine MacKinnon (1985; MacKinnon and Dworkin, 1997) and other feminist scholars of pornography have suggested that there are generally two reasons, both related to distaste for, distance from, or distrust of women, that propel quasi-pornographic descriptions like these. First, the writer is often himself aroused by the recitation; he finds pleasure in describing forced sex (Binder 1995: 298). Second, and related to the first, these descriptions themselves do what the act of rape also does; they put women into a subordinate position (Banks 2000: 100). The judges are writing from a perspective in a socially hierarchical society in which men are actors and women are the ones acted upon. Rape, depending upon one's perspective and the circumstances, is either an example of taking to extremes the norms of a society based upon gender hierarchy (MacKinnon 1989: generally, but especially at 171; Zimmer-Tamakoshi Ch. 2), or it is what happens when some men who believe they should be dominant react with anger to the realisation that they are not (Banks 2000).

\section{The courts' view of rape as a source of emotional injury}

One of the many ways in which feminist studies changed our understanding of rape is by demonstrating that its purpose is seldom about desire (Brownmiller 1975; Groth 1979; Bourne 2007). Contrary to accepted wisdom, the primary purpose of rape is not sexual; the purpose is equally, if not entirely, to subjugate a woman, to wreak violence upon her, to hurt and degrade her. Rape is, for a man, an opportunity to take the thing he most fears about women - their ability to use his own sexual urges to entrap him, encircle him, make him feel weak and needy - and turn that upon a woman; to use his own weakness as a weapon against her. ${ }^{7}$ If men choose to take out their anger at and fear of women through rape, it is because sex is, to men, the most frightening act of all. Because, in sex, the man feels himself succumbing to the woman, becoming weak, needing her, he, at the same time, loves it and abhors it, wants it and fears it, adores it and is disgusted by it.

7 Wardlow (2006) points out that encirclement is very much the fate of Papua New Guinean women, who are beset by boundaries. Yet another paradox of sex in patriarchal cultures is that, while it is women who are, for most important (and unimportant) purposes the encircled, bounded ones, it is men who feel it and fear it. 
The link between rape and masculine anger is made patent in PNG where so many rapes are done by gangs of criminals as a postscript to the act of armed robbery. The circumstances of these rapes as well as the way that they are carried out demonstrate that there is very little about sexual desire, and a great deal about the assertion of male power, involved in rape. A pack of men break into a house or a car, threaten the inhabitants with knives or guns, rob them of everything available, and then, almost as if it were an after-thought, abduct the young women to rape them. In addition women are subjected to rape not just by one gang member but by many. They are threatened and cursed at and subjected not just to sex but to various perversions, as well as being dragged far away and, when all the raping is over, forced to walk home naked or halfclothed. These circumstances and acts of violence against women demonstrate that one motivation for rape is an attempt by young men who feel powerless in the face of social change to assert the only power that they do have, and to do so in the crudest of ways (Borrey 2000: 107).

However, although feminist and masculinist scholars both have uncovered these motives in rape, it is not the way judges traditionally view it. Many Papua New Guinean men-even members of PNG's legal profession-continue to believe that men need constant access to sex. They believe that this need is in the nature of men, and that they cannot be blamed if now and then they go a little overboard. In Chapter Six of this volume, Fiona Hukula quotes men who are serving prison terms for rape explaining that they raped women because their wives or girlfriends wouldn't give them enough sex, or their families stopped them from getting married so they just had to find it elsewhere. The offenders may even believe this. More to our point, judicial decisions suggest that even judges may believe this. At least, this view is implicit in many of the rape cases; in a few, it is even stated explicitly. In State v Yali (2006, 'Yali's Case'), for example, the prosecutor is quoted as saying, 'The offender was at the time a married man who also had a second, de facto, wife. There was no need for him' to rape yet another woman. And if the offender had been single, without even a girlfriend, then would this prosecutor have said, 'Oh, okay, I understand what made you do it. Guess we won't charge you today.'

To some degree, however, lawyers and judges seem to have understood that the major purpose of rape is not to gratify innocuous sexual desires, but to hurt and degrade women, and judges say so in many of their sentencing decisions. However, few judges are able to say this persuasively or movingly, in large part because an odd thing happens in the minds of the judges who hear rape cases, and in the minds, too, of the lawyers who try these cases. Even though they know, in theory, that rape is degrading and painful to women, and that many of the victims will carry lifelong scars from the experience, very few of the male judges or lawyers seem able to empathise with the women. Although the judges 
say that they understand that rape is extremely painful physically; and equally painful emotionally, the tone of their writing suggests that this may be what they think, but not what they feel. The judges do write about the horror of rape for women, but, for the most part, the writing lacks credibility, urgency, and emotional force. It is as if the writer believes he ought to say this, but he isn't feeling it (see Zorn 2010 for detailed evidence).

\section{Two contrasting cases of empathy in gang rape}

Two contrasting cases demonstrate the judges' reluctance to believe in women's emotional pain: the first by atypically recognising the emotional pain and the second by downplaying the pain that the woman surely suffered. The victims in both cases were expatriates. In PNG, the largest number of rape victims is, by far, indigenous women, and I am not focusing in this section on expatriates because I think their cases any more important; quite the opposite. But the choice of these cases helps to illustrate the vagaries of empathy among the judges.

In State v Koupa (1987), a young Australian woman, Christine (whose name we can use because it is given in the decision - a public document), was living with her husband in Hohola when she was the victim of a gang rape. The judge in that case, an Australian himself, believed fully that Christine's physical and psychological injuries were severe enough to warrant making the defendant's sentence even longer than the court otherwise would have made it. Contrast that case with State $v$ Kaudik in the same year. In that case, the young woman who was not named in the judge's decision, and whom we have called Moira, was also the victim of gang rape. The judge in that case, a Papua New Guinean, hardly even discusses the possibility of emotional injury, and certainly does not hold the defendants responsible for having caused the victim much in the way of psychological distress.

One key reason for the differences in the judges' reactions in the two cases lies in what kind of information the prosecuting lawyers in each case provided to the court. In Koupa's Case, one key reason that the judge believed in the emotional pain that Christine experienced was that lawyers for the prosecution gave the court a specific, graphic account, not of how the rapists behaved, but of how she acted during the rape, which demonstrated the depth of her fear and emotional pain in tangible, provable ways. The prosecution reported to the court: that Christine cried during the rape; that her rapists threatened to kill her because she was screaming; and that when the police found her she was shivering from shock. These graphic manifestations of her emotional pain made it real for the court-made it credible. Moreover, the prosecution stated that a year after the event Christine was still undergoing psychiatric treatment 
for the emotional trauma she had sustained. Psychiatrists are experts; courts believe them; the report that the victim was under a psychiatrist's care made her emotional injuries real, almost tangible.

The material supplied by the prosecution in Kaudik's Case was starkly different. It is clear from her affidavit that Moira wished to appear plucky; she wanted to be brave; she did not want to discuss how frightening it all was. Indeed, she was plucky. She had the presence of mind to count her attackers and to try to remember what they looked like. Instead of screaming and crying, she 'lay there and pretended it was not happening'. The prosecution would have done better if Moira had been frailer. Brave young women do not excite the judges' sympathy enough for them to order long prison sentences for their attackers. While Christine's primary rapist was sentenced to eighteen years, Moira's was sentenced to only twelve years. ${ }^{8}$

Koupa's Case is one of the very few in which prosecutors are quoted as having introduced evidence of the victim's emotional condition. More prosecuting lawyers should learn from this case. Or perhaps they cannot. The way in which people demonstrate their emotions is a product of their socialisation, even when those emotions are being experienced under extreme distress (Lutz 1998). Christine cried, screamed and shivered uncontrollably. Moira lay there and pretended she was somewhere else. Not every woman from every culture would react in the same way. In some cultures, the most likely manifestation of fear would be absolute stillness, a sinking into oneself. It would take a great deal of laying of groundwork for a prosecutor to use that behaviour as proof that the victim suffered extensive emotional or psychological injury.

Perhaps the judge in Christine's case was more likely to believe that her emotional injuries were real and severe, because she was an Australian, and so was he. In PNG, for a long while, the bias against women was exacerbated, because there was also a bias, at least amongst some Australian judges, against Papua New Guinean women (Crenshaw 1991: 1270-71). White judges could write with real feeling about the terrible effects that rape must have on a white woman, and find none of that emotion accessible when the victim was Papua New Guinean.

The attitude of judges towards women who are victims of rape depends very much on stereotypes of different kinds of women. Kimberlé Crenshaw coined the term 'intersectionality' to point out that black women are subjected to a double bind; they are prejudiced against both because of their race and because of their

8 Although both women were raped by gangs of men, in each of the reported cases only one defendant was being tried. This is a common practice in the PNG courts. We do not have information on what happened to the other members of the gangs, but it is likely that some escaped the police's notice, and that others pleaded guilty, on the assumption that if the court found one of the gang guilty, it would most probably find others guilty as well. 
gender, and this double prejudice does not lead merely to more discrimination but to discrimination of different kinds. Writing about judges' responses to rape cases in the United States, Crenshaw (1991) noted that judges were more likely to believe that, because of the historical position of black women, they had consented to sex and therefore had suffered no real pain. As slaves, they had been at the mercy of the sexual urges of white masters. Since society did not care to blame slave owners for these sexual assaults, the blame was shifted to the hapless women, who were deemed sexually promiscuous. Papua New Guinean women suffered similar treatment during the colonial period, when they endured the sexual advances of kiaps and planters. Unwilling to blame themselves for this, white Australians deemed Papua New Guinean women 'soiled goods', immoral and promiscuous. Thus the double bind: because Papua New Guinean women were presumed to be immoral and promiscuous, men continued to take advantage of them.

\section{Sentencing guidelines}

Judges' fearful, emotional and, at times, pornographic perceptions of women and rape have infiltrated the sentencing aspect of rape cases in a number of respects. These perceptions are evident not only in the ways in which the judges explicitly talk about the victims and the crime, but in the very guidelines that the judges have devised to shape sentencing decisions. These guidelines, whose purpose is supposed to be to ensure that judges determine sentences rationally and fairly, are imbued with non-rational attitudes towards women and rape. The overall principles for sentencing in rape cases are laid out in the PNG Criminal Code, but these statutory mandates are quite general, and could lead to great disparities in sentencing, so the courts have tried to make them more predictable by establishing more specific guidelines. The guidelines seem to emanate from the judges' masculinised beliefs about women, as do the ways in which the judges apply the guidelines.

Prior to the amendment of the Criminal Code in 2002, the applicable provision of the Code, then Section 347, stated that the penalty for rape was, 'subject to Section 19, imprisonment for life'. That hurried reference to Section 19 was all important, because Section 19 provided that any offender liable for a lifetime prison term could be sentenced to imprisonment for any shorter term, or ordered to pay a fine, or even given a suspended sentence. Courts thus had almost complete leeway in determining the sentence for rape, all the more so because they interpreted the statute to require a life sentence only for the 'worst types of the crime of rape'. However, the latitude is not quite as wide as might appear, because courts do some policing of themselves. Judges do not like to be unduly dissonant in sentencing. Common law notions of fairness, coupled with 
the desire not to have their sentences overturned by an appellate court, propel most judges to believe that the sentence for one offender should, all else being equal, roughly approximate the sentence handed down to a similar offender for a similar crime. A large part of judicial thinking about sentences, then, takes the form of a search for ways to achieve that equivalence between offenders, while also achieving the four goals of criminal sanction, mentioned above.

\section{Creation of the rape-sentencing guidelines}

In 1987, in the two otherwise unrelated rape cases, State $v$ Kaudik (Moira's case) and State $v$ Aubuku, the Papua New Guinean courts, as part of their search for fairness and efficacy, established guidelines that they could follow in rape sentencing. The judges in both these cases adopted, as 'starting points' for rape sentences, the same terms that had been adopted a year earlier in England, even quoting from $R v$ Billiam, the English case. ${ }^{9}$

Although a total of four judges, two of them Papua New Guineans, opined that this formulation was appropriate to PNG, these starting points fail to take into account important differences between the circumstances in England and PNGdifferences that have caused judges in subsequent cases great difficulties when they attempted to apply the guidelines. For example, the per capita incidence of rape in PNG is much higher than in England. Second, pack rapes, which have become endemic in PNG, are rare in England. Given these disparities, it might have occurred to the judges that longer sentences and other more stringent measures not contemplated by the English courts would be needed in PNG.

It may be, however, that the pervasive nature of rape in PNG was not yet apparent to the judges in 1987. Pack rape was just beginning to rise to the consciousness of the courts as a widespread problem that had to be addressed. The starting sentence of eight years for pack rapes must have seemed at the time a considerable leap from past sentencing practices. Prior to 1987, sentences for rape tended to be a lot less than ten years, many were under five years. A striking example of the very short sentences then usually handed down is Acting Public Prosecutor $v$ Konis Haha (1981). The trial court sentenced the two defendants to

9 'For rape committed by an adult without any aggravating or mitigating features, a figure of five years should be taken as the starting point in a contested case. Where a rape is committed by two or more men acting together, or by a man who has broken into or otherwise gained access to a place where the victim is living, or by a person who is in a position of responsibility towards the victim, or by a person who abducts the victim and holds her captive, the starting point should be eight years.

'At the top of the scale comes the defendant who has carried out what might be described as a campaign of rape, committing the crime upon a number of different women or girls. He represents a more than ordinary danger and a sentence of 15 years or more may be appropriate.

'Where the defendant's behaviour has manifested perverted or psychopathic tendencies or gross personality disorder, and where he is likely, if at large, to remain a danger to women for an indefinite time, a life sentence will not be inappropriate' (see State $v$ Kaudik and State $v$ Aubuku from $R v$ Billiam). 
only three years each for rape, with five months each added on for robbery. The men had attacked a soldier and his girlfriend who were walking home from a party, robbing both at knife point and raping the woman. And perhaps the PNG judges did recognise that crime in PNG needed different treatment from that in England. In both Kaudik's and Aubuku's Cases, the judges sentenced defendants to longer terms than had been the norm up to that time. In Kaudik, for example, the first case of pack rape in which the new guidelines were applied, Justice Amet sentenced the defendant to a term of twelve years. Even in the Aubuku case, which did not involve pack rape, the trial court sentenced the defendant to ten years.

\section{Applying the guidelines: Aggravating factors}

The sentencing guidelines adopted in Kaudik's and Aubuku's Cases provided for sentences to be longer if there were aggravating circumstances, and perhaps shorter if there were mitigating circumstances. Quoting from the English case, the judges in Kaudik and Aubuku listed the aggravating factors:

(i) violence over and above the force necessary to commit rape;

(ii) use of a weapon to frighten or wound the victim;

(iii) the rape is repeated;

(iv) the rape has been carefully planned;

(v) the accused has previous convictions for rape or other serious offences of a sexual or violent kind;

(vi) the victim is subjected to further sexual indignities or perversions;

(vii) the victim is either very old or very young; and

(viii) the effect upon the victim, whether physical or mental (State $v$ Kaudik 1987).

'Where any one or more of the following aggravating factors are present the sentence should be substantially higher than the suggested starting point [of 8 years]' (State $v$ Kaudik). Most of these factors are present in most of the PNG cases - especially those relating to violence, the use of weapons, and the subjection of the victim to further indignities.

\section{Violence as an aggravating factor}

As I noted above, PNG's male judges, whether Australian or Papua New Guinean, do not view rape itself as particularly painful. Their definition of aggravated 
rape - which includes a situation in which 'violence is used over and above the force necessary to commit the rape' - suggests that they do understand that the act of rape itself usually involves some degree of force and violence. But they differentiate between the fear produced in a victim by the threat of violence and actual violence. In Waim v State (1997), for example, two university students, the victim and her boyfriend, were walking towards the campus. Accosted at the campus gates by the appellant and five or six other men, the boyfriend was chased into the campus, and the girl was carried away:

Seven of them took turns in raping the victim. She was also forced to engage in oral sex and was further subjected to sexual perversions and indignities. The gang with the victim then headed back towards ... the Waterboard Station at which they stopped the vehicle. The victim was then raped in turn by the appellant and his six accomplices. This forced sex was indulged in vaginally, orally and anally. Then proceeding further into the bush, the victim was once again subjected to forced sexual intercourse by the appellant and the other members (Waim $v$ State).

The trial court sentenced the appellant, who was characterised as the person who first accosted the couple and as the ringleader of the group, to a total of twenty-five years on four counts of rape. On appeal, a three-judge panel (two Papua New Guineans and one Australian) was supposed to weigh these facts against the sentencing guidelines to determine whether that sentence was proper. The panel's decision that the sentence was excessive and its substitution of an eighteen-year sentence were based upon a number of considerations. Most important for our investigation at this moment is the court's finding that, though the victim had been made to suffer 'a harrowing and terrible experience at the hands of the appellant and his accomplices', nonetheless:

There were no weapons used, and no violence other than that associated with forced sexual intercourse was involved here. No life was lost here. And there is no evidence of any long-term injuries sustained by the victim, although it was a terrible experience (Waim $v$ State).

Even the fact that the young woman was raped-not just by one person but by an entire gang-did not shake the court's assurance that no aggravating violence had occurred. The old English and Australian rule was that a woman could prove she had been raped - that she had not been consenting to mutually agreeable sex-only if she had the cuts and bruises that would show she had fought off her attacker. Although that rule has been discredited when it comes to proving whether a rape occurred, it seems that a similar notion is still pervading the sentencing part of rape decisions in PNG. Rapists will serve a minimal sentence unless their victim can show that, in addition to raping 
her, they performed other acts of violence. In fact, the way the rule is worded, rapists will serve a minimal sentence, even if they have acted violently, so long as they can show that they used only as much force as was necessary to enable them to commit rape.

\section{Rape by a person in a position of trust and responsibility}

James Yali was a married man, forty-one years old, Governor of Madang Province and a Member of Parliament from Madang, when he raped the seventeen-yearold sister of the woman he was living with. The rape-sentencing guidelines provided for a higher 'starting point' (eight years, rather than five) if the rapist was in 'a position of responsibility' towards his victim and, since the adoption of the guidelines, the PNG courts have tended to add even more than three years to the sentence of any rapist who has breached a position of trust.

There is no definition of 'position of responsibility' either in the Criminal Code or the cases that originally set out the guidelines, so it is left up to the courts to fill in the substance. A 'position of responsibility' is a role or status and, as such, can be defined in two different ways - either formally or functionally. A formal definition would create a list of relevant positions and the rule would then apply automatically to anyone in such a position, and not to anyone else. A functional definition, however, would describe the purposes or properties of the role, and the rule could then apply to anyone fulfilling these purposes or having these properties, regardless of the formal name of their position. The Supreme Court had ventured to rule on the topic in Meaoa's Case (1996), decided ten years before Yali. But that decision left both arguments open to the participants in Yali's Case, because, in Meaoa, the court had, in essence, subscribed to both. The Meaoa court held that certain relationships (such as parent/child or teacher/pupil) are, by their nature, positions of trust, a formalist definition. And, in addition, the way in which a person 'conducts himself can give rise to a relationship of trust; and ... if such a relationship is violated, it is an aggravating factor' - a functionalist definition.

In Yali's Case, not surprisingly, the defence and the prosecution each argued that the court should adopt the definition that would work best for their side. Counsel for the defendant argued that the phrase should be interpreted formalistically. It connoted, he said, persons who were in certain positions in relation to the victim, such as 'her counselor, basketball coach, physiotherapist, doctor, schoolteacher or someone similar.' Not only was the defendant not in any of these positions, but 'he was her big sister's boyfriend. He was just the sort of person who should not have been trusted [emphasis added].' Counsel for the prosecution, on the other hand, argued that the phrase should be interpreted 
functionally: 'The offender was living in a de facto relationship with the victim's sister. He was providing shelter to the victim and her family. Therefore, she was entitled to trust him.'

Counsel for the prosecution did not base his argument solely on functionalism, however. He also pointed out that, under some neo-customary conceptualisations, Yali, who was formally married to another woman but living with the victim's older sister, could be said to be the de facto husband of the victim's sister and, thus, could be shoehorned into the formalist definition as a kind of brotherin-law to the victim. Having done that, the court was able to use this as an aggravating factor in assessing a sentence of imprisonment for twelve years. Like the prosecutor, however, the court did not base this conclusion on custom; in fact, the judge does not give any provenance for this finding, other than the facts of Yali's living arrangements. In rape cases, the 'position of responsibility' is almost always viewed as a relationship of the rapist to his victim. Yali's case added another dimension because, as a Member of Parliament and Provincial Governor, Yali could be said to have a position of responsibility not only to his young victim, but to the country as a whole. This is not an interpretation of the term that had arisen in earlier PNG cases, but the judge in this case asked counsel to comment on the relevance of Yali's governmental position to the sentencing decision.

Yali's counsel argued, of course, that it was utterly irrelevant. He argued that, for purposes of rape cases, 'position of responsibility' is to be defined solely in relation to the victim. Therefore, Yali's governmental position would be relevant only if they aided his access to or control over the victim, or if his governmental power caused the victim to fear him. Counsel for the State disagreed, suggesting that the definition has to be broadened to include responsibilities beyond those that the defendant had to the victim. The court agreed with the prosecution, holding that 'the offender's status as a member of Parliament and as the Provincial Governor is something that aggravates the offence.' In an era when most people see elected office primarily as a means of self-aggrandisement, this case becomes a precedent with import beyond rape and sentencing.

\section{Disturbing traditional village harmony and discouraging development as aggravating factors}

As more Papua New Guineans became judges, and as more of them came out of a legal education dominated by Papua New Guinean lecturers, they began to add to the list of aggravating factors some that are particular to Melanesian 
cultural mores. For example, in an important set of decisions in 2004, Justice Kandakasi identified the rapists' disruption of the peace, security and unity of the extended family unit as an aggravating factor: ${ }^{10}$

This was a gang rape, which also involved some element of breach of trust the victim placed in you.... This makes the commission of the offence by you three men in the way you did very serious. This is because ... there is already so much danger for our women, girls and children in the streets. Therefore, the village and the family unit and relations are the only place where our women, girls and children could turn to for their protection. Hence, a commission of an offence against a member of one's own community, village, family and other close relations destroys the remainder of any sense of security and hope for living. It also sends a wrong signal to outsiders that the chances of people like you attacking them are far greater. Therefore, they should not come to this province to help it to develop.... Thus, the commission of the kind of offence you committed in the particular setting of your case has the potential of contributing to a destruction of the province to a greater deal, as it has the potential of preventing other people with ability to help develop the province from coming out of fear over theirs and their families' security (State v Sasoropa (No 2) 2004).

What makes Justice Kandakasi's decision unusual is not just his references to traditional Papua New Guinean village life, but also his ability to combine the traditional and the modern, village unity and provincial development, customary law and the formal legal system. This blending was what the drafters of the Constitution had hoped would happen in the Papua New Guinean court system, but their hopes have been, until recently, little realised (Zorn 1991, 1992).

In that case, the perpetrators were members of the same extended family as their victim. In Setep $v$ State (2001), another decision in which Justice Kandakasi participated, the rapists were not related to the family whose home they invaded, though they were known to their victims:

The appellant and his accomplices ... committed the unlawful acts with full knowledge of the identity of the victims for no reason whatsoever save only to commit the acts against the victims. They also made their unlawful intentions known. This kind of conduct is the very cause of break down in community respect and trust and consequently a break down in our society. It is already worse that serious offences are

10 State v Sasoropa, Aremeiko and Melton (2004); State v Paulus Moi \& Clement Samoka (2004); State v Donald Angavia (2004); State v Sina (2004). 
committed outside the family or community units. When they creep into those units it renders no place else safe not even a dwelling house (Setep v State 2001).

The focus on clan and family solidarity - the suggestion that housebreaking, robbery and rape are even more reprehensible when done to people one knows, to people to whom one might have a kinship connection-seems to be an articulation of customary PNG values. In making these observations, Justice Kandakasi is making comprehensible to Papua New Guineans the notion that rape is a serious crime. He is also doing something that, from the colonial era onwards, western-educated judges found impossible to do: he is melding customary values and norms into the imported legal system (Zorn 1991, 1992). The problem, of course, is that, albeit implicitly, it characterises rapes committed against foreigners, whether westerners or Papua New Guineans from another village or region, as not quite so bad. In doing so, it demonstrates, without discussion or resolution, one of the key conflicts between the formal legal system (which positions itself as impartial, at least as between citizens) and customary law (which privileges the 'in group'). Prior to the creation of the state, the 'in group' consisted almost exclusively of kin and fellow villagers.

\section{Changes to the sentencing guidelines: The increasing rate of rape}

By the mid-1990s, it had become apparent to many of the judges that the sentences mandated by their guidelines had not succeeded in lessening the incidence of rape in PNG. Sentences had increased, but so had the prevalence and brutality of rape. Some of the judges became convinced that even higher sentences were needed and they wanted to change the guidelines. Parliament, too, grew uneasy and, as part of the Sexual Offences Act, enacted new sentencing rules which also seemed intended to mandate longer sentences.

\section{Judge-made changes}

The judges who are currently deciding rape cases differ from the judges of twenty years ago, and separate into two camps: those who are able to bridge, or even ignore, PNG's huge gender gap and to appreciate and understand women as human beings; and those for whom the gender gap looms larger than ever. Moreover, the willingness of judges to embrace new approaches to sentencing in rape cases - whether the new approach consists of a change to their own guidelines or to an appreciation of the statutory changes - correlates with the judges' perceptions of women. 
One would think it would be easy for the courts to change the guidelines that they themselves have created. However, the common law is inherently conservative: one of its basic principles (stare decisis) requires that in the absence of extraordinary circumstances, judges do not change rules once they have made them. The principle of stare decisis guarantees consistency in legal decisions, whilst still permitting the law to change gradually to meet society's changing needs and circumstances. When it has come to changing the guidelines for rape sentencing in PNG, some judges have found it easier to argue for immediate change than have others, and the difference seems to turn on the judge's view of women. Judges like Justice Kandakasi, recognising the humanity of women and seeing their welfare as important, argue strongly for instantaneous change. Other judges agree that some increase in sentences is necessary, but find that the law's demands for stability and predictability move them more than the social problems and human pain that rape has caused, and therefore argue that any change should come slowly and by degrees.

Waim's Case (1997) was among the first in which the judges of the Supreme Court admitted that the sentences possible under the guidelines were not succeeding in decreasing either the prevalence or viciousness of rape in PNG. In Waim, a university student was abducted by a gang of seven men, threatened with death, raped at least four times by each of the men and subjected by them to oral and anal sex and other 'sexual perversions and indignities'. The trial court sentenced the ring leader to sentences of eight, fifteen, twenty-five and eight years respectively for each of the four rapes, and ordered that the four sentences be served concurrently, which meant that the defendant would serve a maximum of twenty-five years, significantly above the maximum sentence that had been handed down for rape at that point. The trial judge argued that the vicious nature of this particular rape, and the increasing number of gangrelated rapes, made longer sentences necessary. On appeal, a three-judge panel of the Supreme Court agreed with the trial judge that longer sentences were becoming necessary in order to combat the ever-growing incidence of gangrelated rapes. Nevertheless, the Supreme Court found the twenty-five-year sentence excessive, and substituted a sentence of eighteen years, arguing that the courts should start to impose longer sentences for rape, but ought not to make them too much longer too abruptly.

We are of the respectful view that the sentence of twenty-five years was a 'quantum leap' under the circumstances. A progressive increase in sentencing for particular offences is reasonable and justified, depending on the circumstances of each case. But a sentence that constitutes a huge jump or increase from the prevailing practices ought not be imposed (Waim v State). 
Although the purpose of a written decision is to give the court an opportunity to give the reasons behind its holdings, this court did not give any reasons for holding that sentences ought not to be raised a 'quantum leap'. Nothing beyond its own temerity stopped the court from imposing a twenty-five-year sentence. Or, if it believed it unfair to impose a large increase on defendants without warning or to risk inequality by imposing sentences much longer than those imposed on earlier defendants, it could have said so. It could also have used the opportunity provided by this case to announce an intent to impose longer sentences in every case thereafter. It did neither.

The 'quantum leap' principle is not without critics on the bench, and those foremost are judges whose empathy extends beyond the gender gap. In the important quartet of cases decided in 2004, Justice Kandakasi questioned the efficacy of the principle in the face of rapidly escalating rape statistics, noting that 'there was no expressed [sic] legislative prohibition against "quantum leaps"' (State v Sina No. 2 2004). He did not say so, but he probably intended by this to suggest two things: first, that the courts were not totally bound by the 'quantum leap' rule, as they would be if it had been imposed by statute; and, second, that the principle was part of a whole set of guidelines that the court was in the process of rethinking. In State $v$ Sina, he laid out more substantive reasons for objecting to the quantum leap principle:

[It is] inappropriate that sentencing judges should be unnecessarily limited by concepts such as no 'quantum leaps' or 'disparity in sentencing of co-accused' or such other concepts that have no reflection of the particular circumstances of a case. They should instead be left to be guided by the main purposes of sentencing, such as deterrence, rehabilitation and the rest to meet the society's expectation of stiffer penalties to deter the recurrence of such unacceptable evils in our society (State $v$ Sina).

Before we leave the topic of the court's approach to changing its own guidelines, it should be said, in the court's favour, that, within five years of the Waim decision which had struck down a twenty-five-year sentence, the Supreme Court did impose a twenty-five-year sentence. The court's aim to allow sentences to drift gradually upward was fulfilled. In Setep's Case (2001), the trial judge had imposed a life sentence, because the defendant was a convicted prisoner, already serving thirty years for armed robbery and murder, who had escaped from prison and promptly committed a home invasion, robbery and rape. The Supreme Court refused to impose the life sentence, holding that, yes, longer sentences were needed, but this was too much of a change, too quickly (a 'quantum leap'), and the courts must increase sentences gradually. Despite its 'quantum leap' warning, the appellate panel imposed a twenty-five-year sentence. Since it also held that the twenty-five-year sentence was to be served 
after the defendant finished serving the thirty-year murder sentence, the court had, to all intents and purposes, subjected the defendant to a life sentence, notwithstanding the semantic difference.

\section{Parliamentary changes: But will the courts allow them?}

The Sexual Offences Act of 2002 made a number of significant changes to the laws governing rape, almost all of them in the direction of offering more protection to women and children. One of those changes was a new version of the sentencing rules for rape. Under the old Criminal Code, the PNG courts could punish defendants convicted of rape by any term of imprisonment up to, and including, life (though, as the court held in Setep's Case, a sentence of life was not likely). The courts, in interpreting and applying that sweeping grant of sentencing powers, created guidelines for themselves that resulted in actual sentences that were, except in a few unusual instances, and even after significant increases in sentencing, more in the range of fourteen to nineteen years than life. The two aims of the new Sexual Offences Act were probably, first, to codify the notion of 'starting points' which could be added to for aggravated circumstances and, second, to raise those 'starting points' to a level commensurate with the drafters' view that longer sentences were needed for all rapes, aggravated or not, in order to combat the spreading epidemic of rape.

The guidelines as originally developed by the courts in Kaudik's and Aubuku's Cases had set 'starting points' of five to eight years for non-aggravated rape, with longer sentences for aggravated rape. In recent cases such as Waim, the Supreme Court had indicated a willingness to raise the starting points to ten years, perhaps more. The amendments went beyond that. Section 347(1) of the Criminal Code as amended by the Sexual Offences Act provides for a sentence of 'imprisonment for fifteen years' for rape; Section 347(2), provides that 'where an offence ... is committed in circumstances of aggravation, the accused is liable, subject to Section 19, to imprisonment for life.'

These oddly worded sections have provoked much disagreement in the courts. A major area of disagreement has been over how they relate to each other and, therefore, over the length of sentences that the new Act actually requires. Justice Kandakasi, for example, has interpreted the new provisions to mean that a non-aggravated rape is punishable by any term up to fifteen years and that the punishment for aggravated rape must begin at fifteen years:

[W] here a rape case is not aggravated, it attracts a sentence of up to 15 years. However, where there are aggravating factors, the sentence should be beyond 15 years. If it was otherwise, then this amendment has 
no meaning and purpose because, it makes no difference between the previous position and the new provisions (State $v$ Paulus Moi \& Clement Samoka 2004).

Justice Kandakasi is in all likelihood correct that the drafters of the new provisions intended to create something different from the old Criminal Code. Exactly what, however, is open to question. Justice Kandakasi's view is reasonable, though differing interpretations are possible. He presumes, in effect, that Section 19, which provides that any offender liable for a prison term can be sentenced to imprisonment for any shorter term, or may be ordered to pay a fine, or even given a suspended sentence, is applicable to both sub-sections, so that the fifteen-year sentence for non-aggravated rape is actually a sentence of anything up to fifteen years. Statutes are supposed to be read, however, so as to give meaning to every word in them, and Justice Kandakasi's reading overlooks the differences between the two subsections. Section 347(1) provides unequivocally for a fifteen-year term, with no conditions or qualifications; it reads very differently from Section 347(2) (the subsection dealing with aggravated rape) in two major respects: first, Section 19 is mentioned only in Section 347(2), not in Section 347(1); and, second, Section 347(2) uses the term 'liable' (as in: defendant is liable for a life term, not: the punishment is a life term), whereas Section 347(1) states baldly that the sentence 'is' fifteen years.

These differences in wording could suggest that the drafters intended that everyone found guilty of non-aggravated rape serve a fifteen-year sentence, whereas those found guilty of aggravated rape would be liable for any sentence from fifteen years up to (and including) a life term. This reading equates the new statute's provisions more closely to the court-made guidelines, which stipulated a 'starting point' sentence that would apply to all non-aggravated rapes, and then adding more years to that for each aggravating circumstance. The only notable difference, then, between the guidelines and the new statute would be the length of the 'starting point' sentence, which in the guidelines was five to eight years and in the new statute is fifteen years.

No Papua New Guinean judge has adopted my interpretation of the statuteprobably because judges like to believe that sentencing is a judicial prerogative, not to be usurped by statute, and my reading would limit their discretion in nonaggravated cases. At least, Justice Kandakasi's interpretation hews fairly closely to the spirit, if not the letter, of the guidelines. Some of the judges have come up with interpretations of the new statute that actually undermine what the statute had intended to accomplish - especially if one presumes that one of the statute's aims is to ensure longer sentences. Not surprisingly, the roster of judges whose interpretations of the statute lead to shorter sentences are those whose empathy for women is severely limited. Justice Cannings, for example, in State $v$ Yali, held that defendants cannot be sentenced for anything more than fifteen 
years, even if the rape was aggravated, unless the prosecutor's initial charge stipulated that defendants were charged under Section 347(2), and not 347(1). This interpretation has the result of making it even more difficult for courts to impose longer sentences than it was under the old guidelines, in that it requires an extra step for the prosecutors, who now must remember which section of the Code to charge defendants under, something that was not previously a requirement. Applying his arcane little rule, Justice Cannings decided there was no way he could sentence defendant James Yali, the forty-one-year-old married Governor of Madang Province, who raped his girlfriend's seventeenyear-old sister, to any more than fifteen years imprisonment. Finding that the rape was done in aggravated circumstances, Justice Cannings still sentenced the defendant to only twelve years - even less than the statute mandated for nonaggravated rape.

That is not the only way in which sexist judges have managed to undermine the new statute. In at least two cases, judges have held that although fifteen years is the highest sentence permissible for non-aggravated rape, the sentence for aggravated rape need not start at fifteen years, but can be anything from (I suppose) zero up to life imprisonment. Justice Cannings' interpretation was followed in at least two egregious cases. In State $v$ Aroko (2005), the defendant came upon the victim, who was carrying her nine-month-old baby, working in the sugar cane field. In order to rape her, he struggled with her, cutting her with his knife and separating her from the baby. Although the trial judge, Justice Manuhu, found that the rape was aggravated, he presumed that Section 347(2) does not stipulate a minimum sentence, and therefore felt free to apply a sentence of only eight and a half years imprisonment - considerably below the average in recent cases that had used the guidelines.

In State v Urika (2006), Justice Kirriwom sentenced the defendant, who had raped an elderly woman, to only five years in prison, although prosecutors had charged the defendant under Section 347(2) with aggravated rape. Justice Kirriwom did not mention whether he could have imposed such a light sentence under Section 347(2), if he had found that the rape had been aggravated. Instead, he held that prosecutors may have charged the defendant properly, but that they had then failed to prove any circumstances of aggravation. Quite the opposite. Justice Kirrowom said it was the victim who was aggravating. She had provoked the defendant because she had not paid compensation that she owed him for malicious comments she had made about his daughter's predilection for white men.

These two judges, Justice Manuhu and Justice Kirriwom, present an interesting new (but actually very old) twist on sexism. They both approach their cases as if nothing in jurisprudence or society has changed in the past thirty years. Neither quotes from any of the key cases; both act as if the new statute was 
just a bunch of meaningless and unimportant words, not something they were really supposed to understand and apply. Both apply - to the men who are the defendants and the women who are the victims - standards that even the more sexist of the judges of the last generation had realised were utterly without foundation. The contrasts between their approach to the law and that of a judge like Justice Kandakasi suggests that rape law in PNG diverges between some people moving forward and others retreating into the past.

\section{Changing patterns of empathy}

Since the mid-1990s some Papua New Guinean judges have begun to write with real feeling about what rape does emotionally to its Papua New Guinean victims. In each of the cases in which a judge has displayed empathy, the victim was a blameless village woman. Among the earliest of these decisions was that of Justice Injia (now PNG's Chief Justice) in State $v$ Penias. In that case, decided in 1994, the nineteen-year-old victim was on her way home from school, when the defendant, a married man in his twenties, accosted her. He wore a mask and threatened her with a bush knife. The judge's sentence of nine years was based in part on his view that the crime of rape is extremely serious:

Rape constitutes an invasion of privacy of the most intimate part of a woman's body. Women become objects of sex and sex alone to men like the prisoner who prey upon them and rape them. But woman are after all human beings just like them. They have equal rights and opportunities as men as guaranteed to them under our Constitution. They are entitled to be respected and fairly treated. They all have the right to travel freely alone or in groups of their own, in any place they choose to be at any time of the day. At times, because of their gender, with which comes insecurity, they need the protection of men. Unfortunately, rape has become a prevalent offence in this country. Women in towns and in villages are living in fear because of the pervasive conduct of men like the prisoner. Our women in the small communities in the villages and remote islands and in small towns and centres who once enjoyed freedom and tranquillity are living under fear and feel restricted. ${ }^{11}$

The emotional connection evident in this paragraph includes its cri de coeur: 'women are human beings just like men'. Human beings. Just like men. In a society whose deepest structures are predicated on the oppositional difference of the genders, this is a revolutionary notion. Justice Injia writes in a way that not only demonstrates his own empathy, it also has the capacity to persuade his

11 In addition to the typical legal education at the University of Papua New Guinea, Justice Injia had spent a year in the US, earning a Master's degree at Harvard. Could that experience have relevance to his approach? 
readers. One of the ways by which it achieves this is the veracity of its language; this paragraph is not copied from earlier decisions, as happened in many of the cases we have been looking at; it is in Justice Injia's own words. Finally, this is not just a generalised or abstract statement that rape harms women. It demonstrates that harm through specifics: because of the fear of rape, women are not free to move about; they cannot travel in groups; they cannot travel alone. ${ }^{12}$ Not only does the judge himself experience the painful effect of rape on its victims, he succeeds in conveying the immediacy of that experience to his readers.

Two factors have come together to create the judiciary's changing view of women. First, as the years go on, the influences of colonialism wane. In particular, the racism that characterised the colonial mind and that put women in the double bind of intersectionality - subordinated not only because they were women, but also because they were Papua New Guinean - is receding. Judges now, both Australian and Papua New Guinean, come from younger generations, and are less influenced by colonial stereotypes. Second, perhaps it was easier for Justice Injia to recognise that the victim had suffered true emotional pain because she was not a 'town woman' dressed in western clothes, working in an office and otherwise acting in ways that appeared westernised and, thus, overtly sexual. In a particularly lyrical and persuasive moment, Justice Injia mentions urban women - 'women in towns and villages are living in fear because of the pervasive conduct of men like the offender,' he says, and then reiterates: 'Our women in the small communities, in the villages and remote islands, and in small towns and centres, who once enjoyed freedom and tranquility, are living under fear and feel restricted.' But the victim in this case is a 'village woman' and the picture that a reader takes away from these sentences is of a particular brand of traditional Papua New Guinean woman. Perhaps it is easier for the judge - and for his readers - to empathise when they focus on the ways in which a rape would hurt a typical young Papua New Guinean village woman, rather than generalising to some imported notion of the seriousness of rape on women in general.

In Setep $v$ State (2001) the correlation between the judges' empathy and the woman's identity as a traditional village woman is even clearer. The judges themselves make a point of it: The defendant in the Setep case escaped from prison, where he had been serving a thirty-year sentence for wilful murder; he and a fellow escapee forced their way into the victim's home, robbed and

12 Lawyers will notice that Justice Injia is not just describing any old thing that the fear of rape is preventing women from doing; he is taking a Constitutional provision - that all people be free to travel — and making it apparent that women are not being protected by that provision. 
terrorised the family, and abducted a young girl. The two men raped her repeatedly, clubbed her with a baseball bat, broke one of her fingers, and cut her so severely that stitches were required.

The three-judge panel was made up entirely of Papua New Guineans - Justices Sawong, Gavara-Nanu, and Kandakasi - and the victim was a young, unmarried woman from a traditional Papua New Guinean village. Like Justice Injia in Penias' Case, these judges make the victim's pain real to themselves and the reader by itemising the injuries. Two things should be noted about their itemisation. First, they are focusing on her injuries; not on the pornographic details of what the rapists did. Second, the particular injuries on which they focus are those that would be of especial moment in a traditional village milieu:

The victim in the present case, according to the medical evidence was sick, anxious and distressed as a result of the crimes perpetrated against her. No doubt, she was greatly traumatised and broken. Her esteem and pride as a young virgin girl was violated and so was her person.... We can imagine the victim's aspirations of having a good marriage and a family was shattered because of the violent and uncalled for invasion of her person. The victim is going to bear these consequences for the rest of her life. Common sense in these circumstances therefore dictates that her violators be given sentences that would make them feel the consequences of what they did for the rest of their lives as well (Setep $v$ State 2001).

The judges could have focused on the victim's physical injuries - the deep knife cuts, the broken finger - as the trial judge had done, but they chose instead to focus on the emotional injuries. They do not importune their readers to empathise; instead, they elicit empathy by imagining in narrative cadences the consequences for this typical young woman of the village.

One of the common themes of this volume is that the social changes roiling throughout PNG have had a deleterious impact on many men, calling into question their very claims to masculinity, and that the response of many has been to amplify their already negative attitudes towards women. The Penias and Setep decisions, and others like them, suggest that for some men-in particular, for those who have benefitted, both in security and in status from the changes that their society is undergoing - a more mellow perspective may be possible. Judges are certainly in the category of people who have benefitted from the socio-economic changes that PNG is undergoing. Some of them, relatively wealthy, with high social status, their masculinity unchallenged, can afford to be generous to the subordinate gender. Whatever the reason for the change in judicial decision-writing, there seems, in recent years, to be more empathy, at least from some of the judges, and at least towards some categories of women. 


\section{Concluding comments}

The judges seem to be operating at cross-purposes. In the light of the everescalating rape statistics, most judges have opted in recent years for longer sentences, reasoning that deterrence requires it. These cases, however, were decided prior to the enactment of the Sexual Offences Act, which supported the judges' wish for longer sentences, at least where rapes were aggravated. But, with the exception of Justices Injia and Kandakasi, the judges have not responded with any real understanding of the objectives of the new legislation. Instead, they have undermined their own earlier efforts, making it even harder to impose a longer sentence under the new statute than it was under their own guidelines.

Of course, longer sentences, in and of themselves, won't decrease rape-except to the extent that they are keeping people who have already committed rapes in prison, out of society and away from potential victims. There have to be other changes to the law or to culture before the rate of rape will go down. Those changes require that the sexism that is endemic to cultures in PNG be undone. Is that possible? And what would happen to the many cultures of PNG then?

\section{References}

Banks, Cyndi, 2000. Contextualising sexual violence: rape and carnal knowledge in Papua New Guinea. In Reflections on Violence in Melanesia, ed. Sinclair Dinnen and Allison Ley, 83-104. Sydney: Hawkins Press and Asia Pacific Press.

Binder Lisa A., 1995. 'With more than admiration he admired': images of beauty and defilement in judicial narratives of rape. Harvard Women's Law Journal, 18: $265-300$.

Borrey, Anou, 2000. Sexual violence in perspective: the case of Papua New Guinea. In Reflections on Violence in Melanesia, ed. Sinclair Dinnen and Allison Ley, 105-118. Sydney: Hawkins Press and Asia Pacific Press.

Bourke, Joanna, 2007. Rape: Sex, Violence, History. London: Counterpoint.

Brownmiller, Susan, 1975. Against Our Will: Men, Women and Rape. New York: Ballantine Books.

Collier, Richard, 2010. Masculinities, law and personal life: towards a new framework for understanding men, law and gender. Harvard Journal of Law and Gender 33(2): 431-76. 
Connell, R.W., 2005 [1987]. Masculinities. Berkeley: University of California Press.

Coombs, Mary I., 1992. Outsider scholarship: the law review stories. University of Colorado Law Review 63: 683-716

Crenshaw, Kimberlé, 1991. Mapping the margins: intersectionality, identity politics and violence against women of color. Standford Law Review 43: 1241-99.

Dinnen, Sinclair and Allison Ley, eds, 2000. Reflections on Violence in Melanesia. Sydney: Hawkins Press and Asia Pacific Press.

Dowd, Nancy E., 2010. Asking the man question: masculinities analysis and feminist scholarship, Harvard Journal of Law and Gender 33: 415-30.

Fineman, Martha Albertson and Nancy Sweet Thomadsen, eds, 1991. At the Boundaries of Law: Feminism and Legal Theory. London: Routledge.

Foley, Brian J., 2010. Applied legal storytelling, politics, and factual realism. Journal of the Legal Writing Institute 14: 17-52.

Foucault, Michel, 1995 [1975]. Discipline and Punish: The Birth of the Prison. New York: Vintage.

Grbich, Judith E., 1991. The body in legal theory. In At the Boundaries of Law: Feminism and Legal Theory, ed. Martha Albertson Fineman and Nancy Sweet Thamadsen, 61-76. London: Routledge.

Groth, A. Nicholas, 1979. Men Who Rape: The Psychology of the Offender. New York: Basic Books.

Lloyd, Genevieve, 1984. The Man of Reason: 'Male' and 'Female' in Western Philosophy. Minneapolis: University of Minnesota Press.

Lutz, Catherine A., 1998. Unnatural Emotions: Everyday Sentiments on a Micronesian Atoll and their Challenge in Western Theory. Chicago: University of Chicago Press.

MacKinnon, Catharine A., 1985. Pornography, civil rights and speech. Harvard Civil Rights-Civil Liberties Law Review 20: 1-70.

1989. Towards a Feminist Theory of the State. Cambridge, MA: Harvard University Press.

MacKinnon, Catharine A. and Andrea Dworkin, eds, 1997. In Harm's Way. Cambridge: Harvard University Press. 
Ortner, Sherry and Harriet Whitehead, eds, 1981. Sexual Meanings: The Cultural Construction of Gender and Sexuality. Cambridge: Cambridge University Press.

Réage, Pauline, 1981 [1954], Story of O. New York: Ballantine Books.

Strathern, Marilyn, 1988. The Gender of the Gift: Problems with Women and Problems with Society in Melanesia. Studies in Melanesian Anthropology, No. 6. Berkeley and Los Angeles: University of California Press.

Thornton, Margaret, 1998. Authority and corporeality: the conundrum for women in law. Feminist Legal Studies, 6(2): 147-70.

Valdes, Francisco, 1999. Afterword, theorizing 'outcrit' theories: coalitional method and comparative jurisprudential experience. University of Miami Law Review 53: 1265-322.

Wardlow, Holly, 2006. Wayward Women: Sexuality and Agency in a New Guinea Society. Berkeley: University of California Press.

Zorn, Jean, 1991. Making law in Papua New Guinea: the influence of customary law on the common law. Pacific Studies 14(4): 1-34.

1992. Common law jurisprudence and customary law. In Legal Issues in a Developing Society, ed. R.W. James and Ian Fraser, 103-27. Port Moresby: University of Papua New Guinea Press.

2010. The paradoxes of sexism: proving rape in the Papua New Guinea Courts, LAWASIA 2010: 17-58.

\section{List of Cases}

\section{Papua New Guinea}

Acting Public Prosecutorv Konis Haha [1981] PNGLR 205 (Supreme Court).

Aubuku v State [1987] PNGLR 267 (Supreme Court).

Meaoa $v$ The State [PNGLR] 280 (Supreme Court).

Setep $v$ The State (Unreported) SC666 18 May 2001 (Supreme Court).

State $v$ Angavia (No 2) (Unreported) N2590 29 April 2004 (National Court).

State v Aroko (Unreported) N2822 24 February 2005 (National Court).

State v Kaudik [1987] PNGLR 201 (National Court). 
State v Koupa [1987] PNGLR 208 (National Court).

State $v$ Paulus Moi \& Clement Samoka (Unreported Unnumbered) CR No. 256 of 200429 April 2004 (National Court).

State v Penias [1994] PNGLR 48 (National Court).

State v Sasoropa (No 2) (Unreported) N2569 29 April 2004 (National Courtdecision on sentence).

State $v$ Sina (No 2) (Unreported) N2541 21 May 2004 (National Court-decision on sentence).

State $v$ Urika (Unreported, Unnumbered) CR 434 of 200613 October 2006 (National Court).

State $v$ Yali (Unreported) N2989 19 January 2006 (National Court).

Waim v The State (Unreported) SC5192 May 1997 (Supreme Court).

\section{United Kingdom}

$R v$ Billam [1986] 1 WLR 349. 